\title{
Implementasi Pembelajaran Discovery Reasearch untuk Meningkatkan Prestasi Belajar Ekonomi Akuntansi Materi Laporan Rugi dan Laba Pada Siswa Kelas XII IPS 2 SMA Negeri 2 Siak Hulu
}

\author{
Rosliana Harahap \\ SMA Negeri 2 Siak Hulu, Jl. Kubang Raya, No 62, Kubang Jaya, Kec. Siak Hulu, Kabupaten Kampar, Riau, Indonesia \\ Roslianaharahap67@gmail.com
}

\begin{abstract}
This research was based on problems related to economic learning achievement in class XII IPS 2 SMA Negeri 2 Siak Hulu. The solution to this problem was applying discovery research learning. The purpose of this research was to improve the learning achievement of economics through discovery research learning in class XII IPS 2 SMA Negeri 2 Siak Hulu. Based on the results of the analysis, it was found that student learning achievement had increased from cycle I to cycle III, namely, cycle I $(67.6 \%$,), cycle II $(81 \%)$, cycle III $(91 \%)$. The conclusion of this research is that the Discovery Research Method can improve student achievement in SMAN 2 Siak Hulu Class XII IPS 2 for the 2019/2020 academic year, and this learning model can be used as an alternative for implementing learning material in Economics. The teaching model of the Discovery Research Method can make students feel they get attention and the opportunity to express opinions, ideas, ideas and questions. Students can work independently or in groups, and are able to be responsible for all individual and group tasks. The application of learning with the Discovery Research Method has a positive effect, which can increase student learning creativity.
\end{abstract}

Keywords: Discovery Research, Learning Achievement

\begin{abstract}
Abstrak
Penelitian ini didasarkan adanya permasalahan terkait prestasi belajar ekonomi di kelas XII IPS 2 SMA Negeri 2 Siak Hulu. Solusi dari permasalahan tersebut yaitu menerapkan pembelajaran discovery research. Tujuan dari penelitian ini adalah meningkatkan prestasi belajar ekonomi melalui pembelajaran discovery research di kelas XII IPS 2 SMA Negeri 2 Siak Hulu. Berdasarkan hasil analis didapatkan bahwa prestasi belajar siswa mengalami peningkatan dari siklus I sampai siklus III yaitu, siklus I (67.6\%,), siklus II (81\%), siklus III (91\%). Simpulan dari penelitian ini adalah metode Metode Discovery Reasearch dapat meningkatkan prestasi belajar siswa SMAN 2 Siak Hulu Kelas XII IPS 2 Tahun ajaran 2019/2020, serta model pembelajaran ini dapat digunakan sebagai salah satu alternative pelaksanaan pembelajaran materi Ekonomi. Model pengajaran Metode Discovery Reasearch dapat menjadikan siswa merasa dirinya mendapat perhatian dan kesempatan untuk menyampaikan pendapat, gagasan, ide dan pertanyaan. Siswa dapat bekerja secara mandiri maupun kelompok, serta mampu mempertanggungjawabkan segala tugas individu maupun kelompok. Penerapan pembelajaran dengan Metode Discovery Reasearch mempunyai pengaruh positif, yaitu dapat meningkatkan kreatifitas belajar siswa.
\end{abstract}

Kata kunci: Metode Discovery Research, Prestasi Belajar

Copyright (c) 2020 Rosliana Harahap

$\triangle$ Corresponding author: roslianaharahap67@ gmail.com

Email Address: roslianaharahap67@gmail.com

Received 23 November 2020, Accepted 30 November 2020, Published 01 Desember 2020

\section{PENDAHULUAN}

Metode Pembelajaran merupakan sebuah metode transformasi nilai yang sangat penting. Karena ketika model pembelajaran yang digunakan tidak baik, maka nilai yang ditranformasikan juga klurang maksimal. Menurut Robert gagne pembelajaran adalah upaya guru menyakinkan siswa bahwa setiap siswa mempunyai kemampuan persyaratan untuk tugas-tugas belajarnya, menstimulir penggunaan kemampuan siswa sehingga siap menyelesaikan dan mengatur persyaratan belajar. Dengan demikian pengajaran adalah faktor eksternal bagi siswa. Pada situasi belajar, tingkatanbelajar 
yang tepat terdiri dari hal-hal yang berhubungan dengan persyaratan keterampilan intelektual dan melibatkan penggunaan persyaratan belajar. Dengan demikian dapat ditarik kesimpulan bahwa inti dari belajar bagi Gagne adalah perkembangan kemampuan untuk perubahan sikapnya. Gagne menyamakan perubahan sikap itu sendiri dengan belajar. Buku utamanya "The Condition of Learning" menguraikan delapan tingkah laku belajar yang dapat dibedakan sesuai dengan persyaratan belajar yang dihubungkan satu dengan lainya.

Persyaratan dalam pembe;lajaran meliputi pernyataan-pernyataan seperti perhatian, motivasi, dan ingatan dari kemampuan yang dipelajari sebelumnya yang relevan dengan peristiwa belajar saat itu. Oleh karena itu untuk mengenal tingkatan dan keanekaragaman belajar yang terjadi, pertama-tama harus melihat pada kemampuan yang ada dalam siswa kemudian baru kepada situasi perangsangan yang berada di luar siswa. Pengetahuan dari kemampuan baru membutuhkan pengetahuan sebelumnya dari kemampuan yang lebih rendah yang terlibat dalam kemampuan baru tersebut. Sebagai contoh: seseorang yang pada tingkat kemampuan yang lebih tinggi, membutuhkan pengetahuan sebelumnya dari kemampuan yang lebih sederhana. Jadi suatu pengetahuan yang dicapai seseorang dapat dianalisis kemampuanya dari pengetahuan yang lebih rendah. Sesuai dengan uraian diatas penulis tertarik terhadap "Implementasi Pembelajaran Discovery Reasearch Guna Meningkatkan Prestasi Belajar Ekonomi Akuntansi Materi Laporan Rugi dan Laba pada Siswa Kelas XII IPS 2 SMA Negeri 2 Siak HuluTahun Pelajaran 2019/2020”.

\section{METODE}

Penelitian ini merupakan penelitian tindakan (action research), karena penelitian dilakukan untuk memecahkan masalah pembelajaran di kelas. Penelitian ini juga termasuk penelitian deskriptif, sebab menggambarkan bagaimana suatu teknik pembelajaran diterapkan dan bagaimana hasil yang diinginkan dapat dicapai.

Menurut Sukidin dkk (2002:54) ada 4 macam bentuk penelitian tindakan, yaitu: (1) penelitian tindakan guru sebagai peneliti, (2) penelitian tindakan kolaboratif, (3) penelitian tindakan simultan terintegratif, dan (4) penelitian tindakan sosial eksperimental.

Keempat bentuk penelitian tindakan di atas, ada persamaan dan perbedaannya. Menurut Oja dan Smulyan sebagaimana dikutip oleh Kasbolah, (2000) (dalam Sukidin, dkk. 2002:55), ciri-ciri dari setiap penelitian tergantung pada: (1) tujuan utamanya atau pada tekanannya, (2) tingkat Memberi Pertanyaan dan Menjawab antara pelaku peneliti dan peneliti dari luar, (3) proses yang digunakan dalam melakukan penelitian, dan (4) hubungan antara proyek dengan sekolah.

Dalam penelitian ini menggunakan bentuk guru sebagai peneliti, dimana guru sangat berperan sekali dalam proses penelitian tindakan kelas. Dalam bentuk ini, tujuan utama penelitian tindakan kelas ialah untuk meningkatkan praktik-praktik pembelajaran di kelas. Dalam kegiatan ini, guru terlibat langsung secara penuh dalam proses perencanaan, tindakan, observasi, dan refleksi. Kehadiran pihak lain dalam penelitian ini peranannya tidak dominan dan sangat kecil. 
Penelitian ini mengacu pada perbaikan pembelajaran yang berkesinambungan. Kemmis dan Taggart (1988:14) menyatakan bahwa model penelitian tindakan adalah berbentuk spiral. Tahapan penelitian tindakan pada suatu siklus meliputi perencanaan atau pelaksanaan observasi dan refleksi. Siklus ini berlanjut dan akan dihentikan jika sesuai dengan kebutuhan dan dirasa sudah cukup.

\section{Design penelitian}

Menurut pengertiannya penelitian tindakan adalah penelitian tentang hal-hal yang terjadi di masyarakat atau sekelompok sasaran, dan hasilnya langsung dapat dikenakan pada masyarakat yang bersangkutan (Arikunto, Suharsimi 2002:82). Ciri atau karakteristik utama dalam penelitian tindakan adalah adanya partisipasi dan Memberi Pertanyaan dan Menjawab antara peneliti dengan anggota kelompok sasaran. Penelitian tindakan adalah satu strategi pemecahan masalah yang memanfaatkan tindakan nyata dalam bentuk proses pengembangan inovatif yang dicoba sambil jalan dalam mendeteksi dan memecahkan masalah. Dalam prosesnya pihak-pihak yang terlibat dalam kegiatan tersebut dapat saling mendukung satu sama lain. Sedangkan tujuan penelitian tindakan harus memenuhi beberapa prinsip sebagai berikut:

- Permasalahan atau topik yang dipilih harus memenuhi kriteria, yaitu benar-benar nyata dan penting, menarik perhatian dan mampu ditangani serta dalam jangkauan kewenangan peneliti untuk melakukan perubahan.

- Kegiatan penelitian, baik intervensi maupun pengamatan yang dilakukan tidak boleh sampai mengganggu atau menghambat kegiatan utama.

- Jenis intervensi yang dicobakan harus efektif dan efisien, artinya terpilih dengan tepat sasaran dan tidak memboroskan waktu, dana dan tenaga.

- Metodologi yang digunakan harus jelas, rinci, dan terbuka, setiap langkah dari tindakan dirumuskan dengan tegas sehingga orang yang berminat terhadap penelitian dapat mengecek setiap hipotesis dan pembuktiannya.

- Kegiatan penelitian diharapkan dapat merupakan proses kegiatan yang berkelanjutan (on-going), mengingat bahwa pengembangan dan perbaikan terhadap kualitas tindakan memang tidak dapat berhenti tetapi menjadi tantangan sepanjang waktu. (Arikunto, Suharsimi, 2002:82-83).

Sesuai dengan jenis penelitian yang dipilih, yaitu penelitian tindakan, maka penelitian ini menggunakan model penelitian tindakan dari Kemmis dan Taggart (dalam Arikunto, Suharsimi, 2002:83), yaitu berbentuk spiral dari siklus yang satu ke siklus yang berikutnya. Setiap siklus meliputi planning (rencana), action (tindakan), observation (pengamatan), dan reflection (refleksi). Langkah pada siklus berikutnya adalah perencanaan yang sudah direvisi, tindakan, pengamatan, dan refleksi. Sebelum masuk pada siklus I dilakukan tindakan pendahuluan yang berupa identifikasi permasalahan. Siklus spiral dari tahap-tahap penelitian tindakan kelas dapat dilihat pada gambar berikut. 


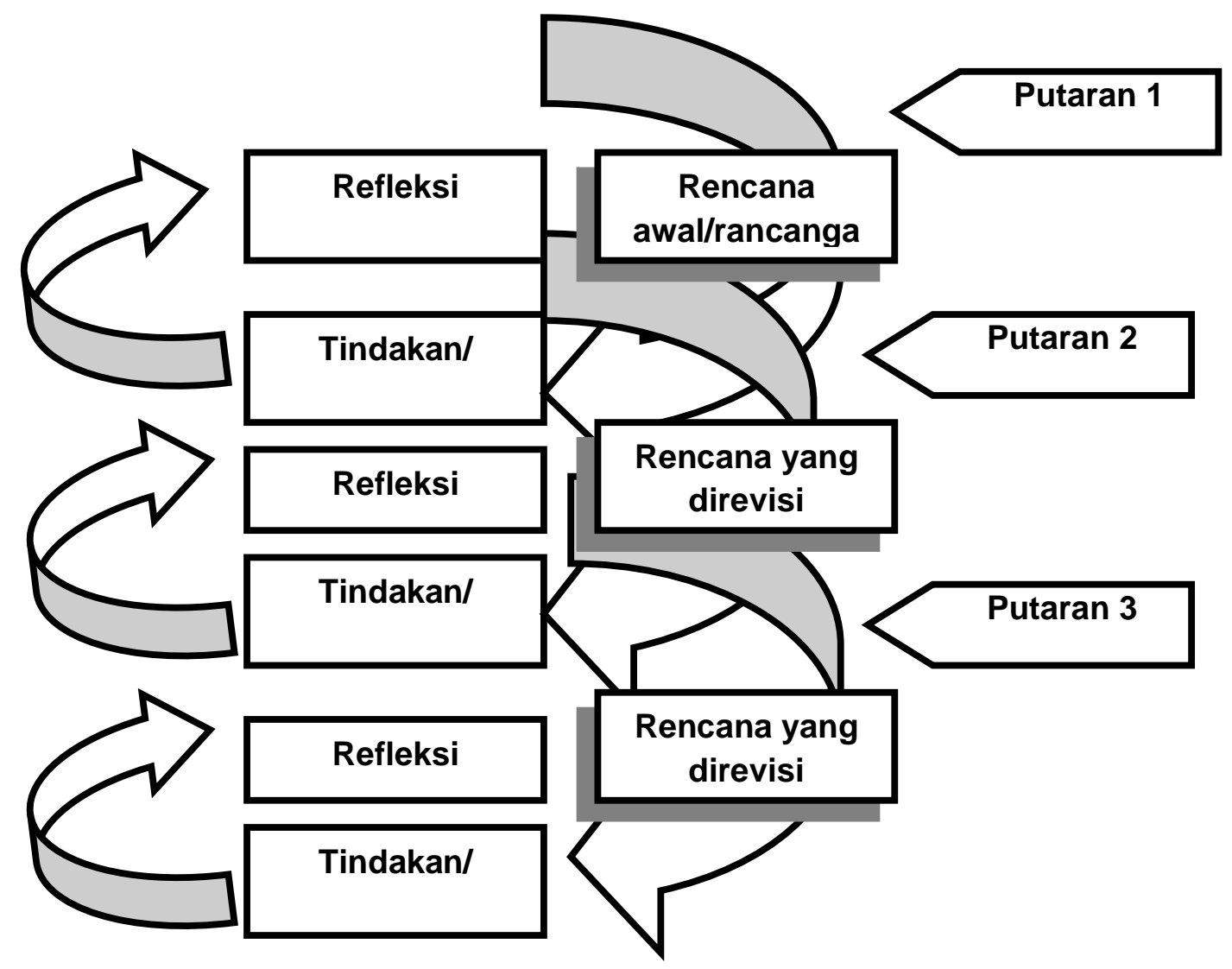

Gambar 1. Alur PTK

\section{Tempat, Waktu, dan Subjek Penelitian}

Tempat penelitian adalah tempat yang digunakan dalam melakukan penelitian untuk memperoleh data yang diinginkan. Penelitian ini bertempat di SMAN 2 Siak Hulu Kecamatan Siak Hulu Tahun Pelajaran 2019/2020. Waktu penelitian adalah waktu berlangsungnya penelitian atau saat penelitian ini dilangsungkan. Penelitian ini dilaksanakan pada bulan Agustus sampai Oktober 2019, semester Ganjil. Subyek penelitian adalah siswa-siswi Kelas XII IPS 2 tahun Pelajaran 2019/2020.

\section{HASIL DAN DISKUSI}

\section{Analisis Data Penelitian Persiklus}

Suatu pokok bahasan atau sub pokok bahasan dianggap tuntas secara klasikal jika siswa yang mendapat nilai 65 lebih dari atau sama dengan 85\%, sedangkan seorang siswa dinyatakan tuntas belajar pada pokok bahasan atau sub pokok bahasan tertentu jika mendapat nilai minimal 65 .

\section{Siklus I}

\section{Tahap Perencanaan}

Pada tahap ini peneliti mempersiapkan perangkat pembelajaran yang terdiri dari rencana pelajaran 1 , soal tes formatif 1 dan alat-alat pengajaran yang mendukung. Selain itu juga dipersiapkan 
lembar observasi pengelolaan Metode Discovery Reasearch, dan lembar observasi aktivitas guru dan siswa.

\section{Tahap Kegiatan dan Pelaksanaan}

Pelaksanaan kegiatan belajar mengajar untuk siklus I dilaksanakan pada tanggal 11 September 2019 di Kelas XII jumlah siswa 36 siswa. Dalam hal ini peneliti bertindak sebagai pengajar. Adapun proses belajar mengajar mengacu pada rencana pelajaran yang telah dipersiapkan. Pengamatan (observasi) dilaksanakan bersamaan dengan pelaksanaan belajar mengajar. Pada akhir proses belajar mengajar siswa diberi tes formatif I dengan tujuan untuk mengetahui tingkat keberhasilan siswa dalam proses belajar mengajar yang telah dilakukan. Adapun data hasil penelitian pada siklus I adalah sebagai berikut.

Tabel 1. Pengelolaan Pembelajaran Pada Siklus I

\begin{tabular}{|c|c|c|c|c|}
\hline \multirow{2}{*}{ No } & \multirow{2}{*}{ Aspek yang diamati } & \multicolumn{2}{|c|}{ Penilaian } & \multirow{2}{*}{$\begin{array}{c}\text { Rata- } \\
\text { rata }\end{array}$} \\
\hline & & $\mathrm{P} 1$ & $\mathrm{P} 2$ & \\
\hline & \multicolumn{4}{|l|}{ Pengamatan KBM } \\
\hline & \multicolumn{4}{|l|}{ A. Pendahuluan } \\
\hline & 1. Memotivasi siswa & 2 & 2 & 2 \\
\hline & 2. Menyampaikan tujuan pembelajaran & 2 & 2 & 2 \\
\hline & 3. Menghubungkan dengan pelajaran sebelumnya & 2 & 2 & 2 \\
\hline & 4. Mengatur siswa dalam kelompok-kelompok belajar & 2 & 2 & 2 \\
\hline & B. Kegiatan inti & & & \\
\hline \multirow[t]{8}{*}{ I } & $\begin{array}{l}\text { 1. Mempresentasikan langkah-langkah metode pembelajaran } \\
\text { kooperatif }\end{array}$ & 3 & 3 & 3 \\
\hline & 2. Membimbing siswa melakukan kegiatan & 3 & 3 & 3 \\
\hline & 3. Melatih keterampilan kooperatif & 3 & 3 & 3 \\
\hline & 4. Mengawasi setiap kelompok secara bergiliran & & & \\
\hline & $\begin{array}{l}\text { 5. Memberikan bantuan kepada kelompok yang mengalami } \\
\text { kesulitan }\end{array}$ & 3 & 3 & 3 \\
\hline & \multicolumn{4}{|l|}{ C. Penutup } \\
\hline & 1. Membimbing siswa membuat rangkuman & 3 & 3 & 3 \\
\hline & 2. Memberikan evaluasi & 3 & 3 & 3 \\
\hline II & Pengelolaan Waktu & 2 & 2 & 2 \\
\hline \multirow{3}{*}{ III } & Antusiasme Kelas & & & \\
\hline & 1. Siswa antusias & 2 & 2 & 2 \\
\hline & 2. Guru antisias & 3 & 3 & 3 \\
\hline \multicolumn{2}{|r|}{ Jumlah } & 32 & 32 & 32 \\
\hline
\end{tabular}

$\begin{aligned} \text { Keterangan } \quad: \quad \text { Nilai } & \text { : Kriteria } \\ \text { 1) } & : \text { Tidak Baik } \\ \text { 2) } & : \text { Kurang Baik } \\ \text { 3) } & : \text { Cukup Baik } \\ \text { 4) } & : \text { Baik }\end{aligned}$


Tabel 2. Rekapitulasi Hasil Tes Formatif Siswa Pada Siklus I

\begin{tabular}{clc}
\hline No & \multicolumn{1}{c}{ Uraian } & Hasil Siklus I \\
\hline 1 & Nilai rata-rata tes formatif & 70,8 \\
2 & Jumlah siswa yang tuntas belajar & 24 \\
3 & Persentase ketuntasan belajar & 68 \\
\hline
\end{tabular}

Berdasarkan tabel di atas dapat dijelaskan bahwa dengan menerapkan pembelajaran dengan Metode Discovery Reasearch diperoleh nilai rata-rata prestasi belajar siswa adalah 70,8 dan ketuntasan belajar mencapai $68 \%$ atau ada 24 siswa dari 36 siswa sudah tuntas belajar. Hasil tersebut menunjukkan bahwa pada siklus pertama secara klasikal siswa belum tuntas belajar, karena siswa yang memperoleh nilai $\geq 65$ hanya sebesar $66.6 \%$ lebih kecil dari persentase ketuntasan yang dikehendaki yaitu sebesar $85 \%$. Hal ini disebabkan karena siswa masih merasa baru dan belum mengerti apa yang dimaksudkan dan digunakan guru dengan menerapkan pembelajaran dengan Metode Discovery Reasearch .

\section{Refleksi}

Dalam pelaksanaan kegiatan belajar mengajar diperoleh informasi dari hasil pengamatan sebagai berikut:

- Guru kurang maksimal dalam memotivasi siswa dan dalam menyampaikan tujuan pembelajaran

- Guru kurang maksimal dalam pengelolaan waktu

- Siswa kurang aktif selama pembelajaran berlangsung

\section{Refisi}

Pelaksanaan kegiatan belajar mengajar pada siklus I ini masih terdapat kekurangan, sehingga perlu adanya revisi untuk dilakukan pada siklus berikutnya.

- Guru perlu lebih terampil dalam memotivasi siswa dan lebih jelas dalam menyampaikan tujuan pembelajaran. Dimana siswa diajak untuk terlibat langsung dalam setiap kegiatan yang akan dilakukan.

- Guru perlu mendistribusikan waktu secara baik dengan menambahkan informasi-informasi yang dirasa perlu dan memberi catatan.

- Guru harus lebih terampil dan bersemangat dalam memotivasi siswa sehingga siswa bisa lebih antusias.

\section{Siklus II}

\section{Tahap perencanaan}

Pada tahap ini peneliti mempersiapkan perangkat pembelajaran yang terdiri dari rencana pelajaran 2, soal tes formatif 2 dan alat-alat pengajaran yang mendukung. 


\section{Tahap kegiatan dan pelaksanaan}

Pelaksanaan kegiatan belajar mengajar untuk siklus II dilaksanakan pada tanggal 25 September 2019 di Kelas XII IPS 2 dengan jumlah siswa 36 siswa. Dalam hal ini peneliti bertindak sebagai pengajar. Adapun proses belajar mengajar mengacu pada rencana pelajaran dengan memperhatikan revisi pada siklus I, sehingga kesalahan atau kekurangan pada siklus I tidak terulang lagi pada siklus II. Pengamatan (observasi) dilaksanakan bersamaan dengan pelaksanaan belajar mengajar.

Pada akhir proses belajar mengajar siswa diberi tes formatif II dengan tujuan untuk mengetahui tingkat keberhasilan siswa dalam proses belajar mengajar yang telah dilakukan. Instrumen yang digunakan adalah tes formatif II. Adapun data hasil penelitian pada siklus II adalah sebagai berikut.

Tabel 3. Pengelolaan Pembelajaran Pada Siklus II

\begin{tabular}{|c|c|c|c|c|}
\hline \multirow{2}{*}{ No } & \multirow{2}{*}{ Aspek yang diamati } & \multicolumn{2}{|c|}{ Penilaian } & \multirow{2}{*}{$\begin{array}{l}\text { Rata- } \\
\text { rata }\end{array}$} \\
\hline & & $\mathrm{P} 1$ & $\mathrm{P} 2$ & \\
\hline \multirow{3}{*}{ I } & $\begin{array}{l}\text { Pengamatan KBM } \\
\text { D. Pendahuluan } \\
\text { 1. Memotivasi siswa } \\
\text { 2. Menyampaikan tujuan pembelajaran } \\
\text { 3. Menghubungkan dengan pelajaran sebelumnya } \\
\text { 4. Mengatur siswa dalam kelompok-kelompok belajar }\end{array}$ & $\begin{array}{l}3 \\
3 \\
4 \\
3\end{array}$ & $\begin{array}{l}3 \\
4 \\
3 \\
3\end{array}$ & $\begin{array}{l}3 \\
3 \\
3 \\
3\end{array}$ \\
\hline & $\begin{array}{l}\text { E. Kegiatan inti } \\
\text { 1. Mempresentasikan langkah-langkah metode pembelajaran } \\
\text { kooperatif } \\
\text { 2. Membimbing siswa melakukan kegiatan } \\
\text { 3. Melatih keterampilan kooperatif } \\
\text { 4. Mengawasi setiap kelompok secara bergiliran } \\
\text { 5. Memberikan bantuan kepada kelompok yang mengalami } \\
\text { kesulitan }\end{array}$ & $\begin{array}{l}3 \\
4 \\
4 \\
4 \\
3\end{array}$ & $\begin{array}{l}4 \\
4 \\
4 \\
4 \\
3\end{array}$ & $\begin{array}{l}3 \\
4 \\
4 \\
4 \\
3\end{array}$ \\
\hline & $\begin{array}{l}\text { F. Penutup } \\
\text { 1. Membimbing siswa membuat rangkuman } \\
\text { 2. Memberikan evaluasi }\end{array}$ & $\begin{array}{l}3 \\
4\end{array}$ & $\begin{array}{l}4 \\
4\end{array}$ & $\begin{array}{l}3 \\
4\end{array}$ \\
\hline II & Pengelolaan Waktu & 3 & 3 & 3 \\
\hline III & $\begin{array}{cl}\text { Antusiasme Kelas } \\
\text { 1. } & \text { Siswa antusias } \\
\text { 2. } & \text { Guru antisias }\end{array}$ & $\begin{array}{l}4 \\
4\end{array}$ & $\begin{array}{l}3 \\
4\end{array}$ & $\begin{array}{l}3 \\
4\end{array}$ \\
\hline & Jumlah & 52 & 54 & 51 \\
\hline
\end{tabular}

$\begin{aligned} \text { Keterangan } \quad: \quad \text { Nilai } & \text { : Kriteria } \\ \text { 1) } & : \text { Tidak Baik } \\ \text { 2) } & : \text { Kurang Baik } \\ \text { 3) } & : \text { Cukup Baik } \\ \text { 4) } & : \text { Baik }\end{aligned}$


Tabel 4. Rekapitulasi Hasil Tes Formatif Siswa Pada Siklus II

\begin{tabular}{clc}
\hline No & \multicolumn{1}{c}{ Uraian } & Hasil Siklus II \\
\hline 1 & Nilai rata-rata tes formatif & 74.3 \\
2 & Jumlah siswa yang tuntas belajar & 29 \\
3 & Persentase ketuntasan belajar & 7 \\
\hline
\end{tabular}

Berdasarkan tabel di atas diperoleh nilai rata-rata prestasi belajar siswa adalah 74.3 dan ketuntasan belajar mencapai $81 \%$ atau ada 29 siswa dari 36 siswa sudah tuntas belajar. Hasil ini menunjukkan bahwa pada siklus II ini ketuntasan belajar secara klasikal telah mengalami peningkatan sedikit lebih baik dari siklus I. Adanya peningkatan kemampuan berbicara siswa ini karena setelah guru menginformasikan bahwa setiap akhir pelajaran akan selalu diadakan tes sehingga pada pertemuan berikutnya siswa lebih termotivasi untuk belajar. Selain itu siswa juga sudah mulai mengerti apa yang dimaksudkan dan diinginkan guru dengan menerapkan pembelajaran dengan Metode Discovery Reasearch.

\section{Refleksi}

Dalam pelaksanaan kegiatan belajar diperoleh informasi dari hasil pengamatan sebagai berikut.

- Memotivasi siswa

- Membimbing siswa merumuskan kesimpulan/menemukan konsep

- Pengelolaan waktu

\section{Revisi Rancangan}

Pelaksanaan kegiatan belajar pada siklus II ini masih terdapat kekurangan-kekurangan. Maka perlu adanya revisi untuk dilaksanakan pada siklus II antara lain:

- Guru dalam memotivasi siswa hendaknya dapat membuat siswa lebih termotivasi selama proses belajar mengajar berlangsung.

- Guru harus lebih dekat dengan siswa sehingga tidak ada perasaan takut dalam diri siswa baik untuk mengemukakan pendapat atau bertanya.

- Guru harus lebih sabar dalam membimbing siswa merumuskan kesimpulan/menemukan konsep.

- Guru harus mendistribusikan waktu secara baik sehingga kegiatan pembelajaran dapat berjalan sesuai dengan yang diharapkan.

- Guru sebaiknya menambah lebih banyak contoh soal dan memberi soal-soal latihan pada siswa untuk dikerjakan pada setiap kegiatan belajar mengajar. 


\section{Siklus III}

\section{Tahap perencanaan}

Pada tahap ini peneliti mempersiapkan perangkat pembelajaran yang terdiri dari rencana pelajaran 3 , soal tes formatif 3 dan alat-alat pengajaran yang mendukung.

\section{Tahap kegiatan dan pengamatan}

Pelaksanaan kegiatan belajar mengajar untuk siklus III dilaksanakan pada tanggal 16 Oktober 2019 di Kelas XII IPS 2 dengan jumlah siswa 36 siswa. Dalam hal ini peneliti bertindak sebagai pengajar. Adapun proses belajar mengajar mengacu pada rencana pelajaran dengan memperhatikan revisi pada siklus II, sehingga kesalahan atau kekurangan pada siklus II tidak terulang lagi pada siklus III. Pengamatan (observasi) dilaksanakan bersamaan dengan pelaksanaan belajar mengajar. Pada akhir proses belajar mengajar siswa diberi tes formatif III dengan tujuan untuk mengetahui tingkat keberhasilan siswa dalam proses belajar mengajar yang telah dilakukan. Instrumen yang digunakan adalah tes formatif III. Adapun data hasil penelitian pada siklus III adalah sebagai berikut.

Tabel 5. Pengelolaan Pembelajaran Pada Siklus III

\begin{tabular}{|c|c|c|c|c|}
\hline \multirow{2}{*}{ No } & \multirow{2}{*}{ Aspek yang diamati } & \multicolumn{2}{|c|}{ Penilaian } & \multirow{2}{*}{$\begin{array}{r}\text { Rata- } \\
\text { rata }\end{array}$} \\
\hline & & P1 & P2 & \\
\hline I & $\begin{array}{l}\text { Pengamatan KBM } \\
\text { A. Pendahuluan } \\
\text { 1. Memotivasi siswa } \\
\text { 2. Menyampaikan tujuan pembelajaran } \\
\text { 3. Menghubungkan dengan pelajaran sebelumnya } \\
\text { 4. Mengatur siswa dalam kelompok-kelompok belajar }\end{array}$ & $\begin{array}{l}4 \\
4 \\
4 \\
4\end{array}$ & $\begin{array}{l}4 \\
4 \\
4 \\
4\end{array}$ & $\begin{array}{l}4 \\
4 \\
4 \\
4\end{array}$ \\
\hline & $\begin{array}{l}\text { B. Kegiatan inti } \\
\text { 1. Mempresentasikan langkah-langkah metode } \\
\text { pembelajaran kooperatif } \\
\text { 2. Membimbing siswa melakukan kegiatan } \\
\text { 3. Melatih keterampilan kooperatif } \\
\text { 4. Mengawasi setiap kelompok secara bergiliran } \\
\text { 5. Memberikan bantuan kepada kelompok yang } \\
\text { mengalami kesulitan }\end{array}$ & $\begin{array}{l}4 \\
4 \\
4 \\
3\end{array}$ & $\begin{array}{l}4 \\
4 \\
4 \\
3 \\
4\end{array}$ & $\begin{array}{l}4 \\
4 \\
4 \\
4\end{array}$ \\
\hline & $\begin{array}{l}\text { C. Penutup } \\
\text { 1. Membimbing siswa membuat rangkuman } \\
\text { 2. Memberikan evaluasi }\end{array}$ & $\begin{array}{l}4 \\
4 \\
\end{array}$ & $\begin{array}{l}4 \\
4 \\
\end{array}$ & $\begin{array}{l}4 \\
4 \\
\end{array}$ \\
\hline II & Pengelolaan Waktu & 4 & 4 & 4 \\
\hline III & $\begin{array}{l}\text { Antusiasme Kelas } \\
\text { 1. } \quad \text { Siswa antusia } \\
\text { 2. } \quad \text { Guru antisias }\end{array}$ & $\begin{array}{l}4 \\
4\end{array}$ & $\begin{array}{l}4 \\
4\end{array}$ & $\begin{array}{l}4 \\
4\end{array}$ \\
\hline & Jumlah & 55 & 55 & 56 \\
\hline
\end{tabular}

Keterangan Nilai : Kriteria

$$
\begin{array}{ll}
1 & \text { : Tidak Baik } \\
\text { 2. } & \text { : Kurang Baik } \\
\text { 3. } & \text { : Cukup Baik }
\end{array}
$$


4. : Baik

Tabel 6. Hasil Formatif Siswa Pada Siklus III

\begin{tabular}{clc}
\hline No & \multicolumn{1}{c}{ Uraian } & Hasil Siklus III \\
\hline 1 & Nilai rata-rata tes formatif & 76.75 \\
2 & Jumlah siswa yang tuntas belajar & 33 \\
3 & Persentase ketuntasan belajar & $91 \%$ \\
\hline
\end{tabular}

Berdasarkan tabel di atas diperoleh nilai rata-rata tes formatif sebesar 76.75 dan dari 36 siswa telah tuntas sebanyak 33 siswa dan 3 siswa belum mencapai ketuntasan belajar. Maka secara klasikal ketuntasan belajar yang telah tercapai sebesar 91\% (termasuk kategori tuntas). Hasil pada siklus III ini mengalami peningkatan lebih baik dari siklus II. Adanya peningkatan kemampuan berbicara pada siklus III ini dipengaruhi oleh adanya peningkatan kemampuan guru dalam menerapkan pembelajaran dengan Metode Discovery Reasearch sehingga siswa menjadi lebih terbiasa dengan pembelajaran seperti ini sehingga siswa lebih mudah dalam memahami materi yang telah diberikan.

\section{Refleksi}

Pada tahap ini akan dikaji apa yang telah terlaksana dengan baik maupun yang masih kurang baik dalam proses belajar mengajar dengan penerapan pembelajaran dengan Metode Discovery Reasearch. Dari data-data yang telah diperoleh dapat diuraikan sebagai berikut:

- Selama proses belajar mengajar guru telah melaksanakan semua pembelajaran dengan baik. Meskipun ada beberapa aspek yang belum sempurna, tetapi persentase pelaksanaannya untuk masing-masing aspek cukup besar.

- Berdasarkan data hasil pengamatan diketahui bahwa siswa aktif selama proses belajar berlangsung.

- Kekurangan pada siklus-siklus sebelumnya sudah mengalami perbaikan dan peningkatan sehingga menjadi lebih baik.

- Kemampuan berbicara siswa pada siklus III mencapai ketuntasan.

\section{Revisi Pelaksanaan}

Pada siklus III guru telah menerapkan pembelajaran dengan Metode Discovery Reasearch dengan baik dan dilihat dari aktivitas siswa serta kemampuan berbicara siswa pelaksanaan proses belajar mengajar sudah berjalan dengan baik. Maka tidak diperlukan revisi terlalu banyak, tetapi yang perlu diperhatikan untuk tindakan selanjutnya adalah memaksimalkan dan mempertahankan apa yang telah ada dengan tujuan agar pada pelaksanaan proses belajar mengajar selanjutnya penerapan model pengajaran Metode Discovery Reasearch dapat meningkatkan proses belajar mengajar sehingga tujuan pembelajaran dapat tercapai. 


\section{Pembahasan}

\section{Ketuntasan Kemampuan berbicara Siswa}

Melalui hasil penelitian ini menunjukkan bahwa pembelajaran dengan Metode Discovery Reasearch memiliki dampak positif dalam meningkatkan prestasi belajar siswa. Hal ini dapat dilihat dari semakin mantapnya pemahaman siswa terhadap materi yang disampaikan guru (ketuntasan belajar meningkat dari siklus I, II, dan III) yaitu masing-masing $68 \%, 81 \%$, dan $91 \%$. Pada siklus III ketuntasan belajar siswa secara klasikal telah tercapai.

\section{Kemampuan Guru dalam Mengelola Pembelajaran}

Berdasarkan analisis data, diperoleh aktivitas siswa dalam proses belajar mengajar dengan menerapkan model pengajaran Metode Discovery Reasearch dalam setiap siklus mengalami peningkatan. Hal ini berdampak positif terhadap prestasi belajar siswa yaitu dapat ditunjukkan dengan meningkatnya nilai rata-rata siswa pad setiap siklus yang terus mengalami peningkatan.

\section{Aktivitas Siswa Dalam Pembelajaran}

Berdasarkan analisis data, diperoleh aktivitas siswa dalam proses pembelajaran Ekonomi dengan model pengajaran Metode Discovery Research yang paling dominan adalah, mendengarkan/memperhatikan penjelasan guru, dan diskusi antar siswa/antara siswa dengan guru. Jadi dapat dikatakan bahwa aktivitas siswa dapat dikategorikan aktif. Sedangkan untuk aktivitas guru selama pembelajaran telah melaksanakan langkah-langkah kegiatan belajar mengajar dengan menerapkan pengajaran konstekstual model pengajaran card short dengan baik. Hal ini terlihat dari aktivitas guru yang muncul di antaranya aktivitas membimbing dan mengamati siswa dalam menemukan konsep, menjelaskan materi yang sulit, memberi umpan balik/evaluasi/tanya jawab dimana prosentase untuk aktivitas di atas cukup besar.

\section{KESIMPULAN}

Berdasarkan hasil penelitian yang telah dipaparkan selama tiga siklus, hasil seluruh pembahasan serta analisis yang telah dilakukan dapat disimpulkan sebagai berikut:

- Model pengajaran Metode Discovery Reasearch dapat meningkatkan kualitas pembelajaran Ekonomi materi laporan rugi dan laba.

- Pembelajaran dengan Metode Discovery Reasearch memiliki dampak positif dalam meningkatkan prestasi belajar siswa yang ditandai dengan peningkatan ketuntasan belajar siswa dalam setiap siklus, yaitu siklus I (68\%,), siklus II (81\%), siklus III (91\%).

- Model pengajaran Metode Discovery Reasearch dapat menjadikan siswa merasa dirinya mendapat perhatian dan kesempatan untuk menyampaikan pendapat, gagasan, ide dan pertanyaan. 
- Siswa dapat bekerja secara mandiri maupun kelompok, serta mampu mempertanggungjawabkan segala tugas individu maupun kelompok.

- Penerapan pembelajaran dengan Metode Discovery Reasearch mempunyai pengaruh positif, yaitu dapat meningkatkan kreatifitas belajar siswa.

\section{UCAPAN TERIMA KASIH}

Terimakasih diucapkan kepada Kepala SMAN 2 Siak Hulu yang sudah memberikan izin dalam melaksanakan penelitian ini. Kepada peserta didik yang sudah berpartisipasi dalam melaksanakan penelitian ini. Kepada pihak Dinas Pendidikan yang sudah memberikan izin dalam dan mendukung dalam melaksanakan penelitian ini.

\section{REFERENSI}

Ametembun, N. A, R. Levancois Guy. 1986. Psychology for Teaching/ Psikologi Untuk Mengajar. Bandung: Intisari.

Arifin, Mulyati, dkk. 2005. Strategi Belajar Mengajar Kimia. Malang: UM Press.

Arikunto,Suharsimi, dkk. 2007. Penelitian Tindakan Kelas. Jakarta: Bumi Aksara.

Djamarah Bakri, Syaiful. 1994. Prestasi Belajar dan Kompetensi Guru. Surabaya: Usaha Nasional.

Hamalik, Oemar. 1991. Pendidikan Guru Konsep Dan Strategi. Bandung: Mandar Maju.

Hamalik, Oemar. 1992. Psikologi Belajar dan Mengajar. Bandung: Sinar Baru.

Hamalik, Oemar. 2007. Proses Belajar Mengajar Jakarta: Bumi Aksara.

Hamalik, Oemar. 2007. Kurikulum dan Pembelajaran. Jakarta: Bumi Aksara.

Iqbal Hasan. 2002. Metodologi Penelitian dan Aplikasinya. Jakarta: Ghalia Indonesia Anggota IKAPI. Meoleong, Lexy J. 2007. Meodologi Penelitian Kualitatif. Bandung: PT Rosdakarya.

Mbulu, Joseph. 2001. Pengajaran Individual Pendidikan, Pendekatan, Metode, , Dan Media Pedoman Mengajar Bagi Guru Dan Bagi Calon Guru. Malang: PT Elang emas.

Purwanto, M. Ngalim. 2006. Psikologi Pendidikan Bandung: Remaja Rosdakarya.

R. Nuryani. 2005. Strategi Belajar Mengajar Biologi. Malang: UM Press.

Roestiyah. 1986. Strategi Belajar Mengajar. Jakarta: Bina Aksara.

Sofa, Pendekatan Discovery, Inquiry Dan STS Dalam Pembelajaran Fisika (http:www.google.com. diakses 09 Oktober 2009)

Sukarno, dkk. 1981. Dasar-Dasar Pendidikan Sains. Jakarta: Bhratara Karya Aksara.

Suroso. 2009. Penelitian Tindakan Kelas. Yogyakarta: Pararaton.

Syaodih Sukmadinata, Nana. 2007. Metode Penelitian Pendidikan. Bandung: PT Remaja Rosdakarya.

Sagala, Syaiful, 2009. Konsep dan Makna Pembelajaran Untuk Membantu Memecahkan problematika Belajar dan Mengajar. Bandung: CV Alfabeta. 
Syah, Muhibbin. 2004. Psikologi Belajar Jakarta: RajaGrafindo Persada.

Uno, Hamzah B. 2007. Teori Motivasi dan Pengukurannya Analisis di Bidang Pendidikan Jakarta: Bumu Aksara.

Usman, Moh. Uzer. 1995. Menjadi Guru Profesional Bandung: Remaja Rosdakarya.

Wahidmurni. 2008. Penelitian Tindakan Kelas (Dari Teori Menuju Praktek). Malang: UM Press. 